\title{
Implementation of the KIR E-Test Program in the Technical Implementation Unit of the Motor Vehicle Testing Service of the Garut Regency Transportation Service
}

\author{
Ikeu Kania \\ Universitas Garut, Indonesia \\ Email: ikeukania@fisip.uniga.ac.id
}

\begin{abstract}
Implementing the KIR e-test program at the UPTD of the Garut Regency Transportation Service has been carried out since October 1, 2019. The KIR e-test program is a service innovation by changing the manual KIR test system using an IT-based system so that the KIR e-test application can simplify and shorten the service time for people who will do the KIR test. This study uses a qualitative method with descriptive analysis. The data collection techniques used include observation, interviews, and documentation. The data analysis technique used is data reduction, data presentation and conclusion drawing. From the results of the study, it was concluded that the implementation of the KIR e-test program had been implemented but encountered several obstacles, including information on changes in testing procedures from manual to electronic has not been informed to the public, so there are still people who think that the testing procedures carried out take a long time, so that vehicle owners prefer to use the services of brokers in testing the UPTD PKB Dishub Garut still lacks testers, especially testers who are certified and do not have a backup of e-KIR infrastructure. Implementing the KIR e-test is still prone to illegal levies because there are still brokers who call themselves service bureaus in collaboration with unscrupulous officers.
\end{abstract}

Keywords: Implementation, Program, E-Test KIR.

\section{A. INTRODUCTION}

The problem of transportation is one of the most critical problems for human needs to support daily activities and support the community's economy (Kadarisman et al., 2016; Kania, 2020). The harmony between public transport users and providers should ideally be good and correct to realize security, safety, order and smooth traffic (Natika \& Putri, 2021). Articles 48 to 55 of Law no. 22 of 2009 concerning Road Traffic and Transportation has stipulated technical and roadworthy requirements for motorized vehicles. It requires that imported, manufactured and assembled motorized vehicles in the country to be operated on the road must be subjected to periodic testing of motorized vehicles carried out every 6 (six) once a month to create transportation that is following the feasibility of being on the road so that users feel safe, comfortable and have confidence in the means of transportation used. The types of vehicles that must be tested include passenger cars, buses, goods vehicles and special vehicles. The stages of testing motor vehicles based on SOPs for motorized vehicle inspections consist of several stages, namely: pre-test, exhaust emission test, inspection of the underside of the vehicle, headlight intensity test, front-wheel knuckle test, scales, brake test, and speedometer test. 2013). 
In its implementation, periodic motor vehicle testing takes a lot of time. Vehicle owners are reluctant to queue and choose to use brokers or pay extortion to get the desired results without participating in a motorized vehicle feasibility test. The vehicle properly so that the policy still has the opportunity for unscrupulous officers to falsify KIR results to help certain parties quickly obtain roadworthy certificates illegally (Septianti \& Prabawati, 2019). By seeing these obstacles, the Garut Regency Transportation Service began on October 1, 2019, to roll out the KIR e-test program, which aims to facilitate services to the community and reduce illegal levies by certain elements.

The KIR e-test is an innovation program to facilitate services to the community and ensure transparency in the administration of the KIR test as stipulated in the Regulation of the Minister of Transportation No. 133 of 2015 concerning Periodic Testing of Motor Vehicles. The KIR e-test is a motor vehicle testing application that utilizing IT so that the KIR e-test application will simplify and shorten the service time for people who will carry out the KIR test. The KIR e-test program covers the registration process up to the testing of motorized vehicles. The registration process can be done online through an application downloaded on the App Store, which all people can access. There are several menus in this application, such as a home menu that contains a check of vehicle data, test results, record status, vehicle history, and test fees (Kuncoro \& Sarbini, 2020).

By using the KIR e-test application, people do not need to queue long to test motor vehicles. The public can register and take a queue number to test through the KIR e-test application. In addition to the ease of registration, by using the KIR e-test application, vehicle testing carried out by the UPTD PKB of the Garut Regency Transportation Service can be monitored as an embodiment of agency transparency to the public. After the registration process, vehicle testing is carried out using ePayment Corner or non-cash; the payment can be through the Bank Jabar counter located at the UPTD PKB of the Transportation Service or all Bank Jabar ATMs. In contrast, for payments made manually at the payment counter, the service is directly handled by Bank Jabar officers without any interference from the UPTD PKB employees of the Department of Transportation. The payment of this KIR test retribution goes directly to the regional treasury. This payment method can reduce illegal levies because there are no more direct payments to the testing officer but through the Bank Jabar counter.

This program is not only in the IT-based registration process. But also in the testing of motorized vehicles that are carried out also based on IT, wherein the testers are already using tablets and PCs (Personal Computers) no longer manually. The tablet is connected to the SIM PKB application, which is interconnected between employees so that tests that usually take hours can be completed in just 30 minutes so that usually in one day, UPT PKB can only complete testing of several motorized vehicles, with this KIR e-test application one day at least can complete 60 vehicles. Vehicle testing using tablets also reduces test results cheating because employees cannot manipulate test result data; the test results automatically appear directly in the 
PKB SIM application without the employees inputting them. Illegal levies are minimized because there are no gaps in manipulating data (Septianti \& Prabawati, 2019).

After testing the motorized vehicle, people who test their vehicle can immediately take the test results at the counter that is already available which in printing the test card is no longer manually but already using a computer system so that initially using a test book it was changed to an electronic KIR card using a card called Blue (Electronic Test Pass Evidence) connected to the Ministry of Transportation. The purpose of this KIR e-test is not only to speed up the testing process, to have transparency and reduce illegal fees as well as to increase the awareness of users and vehicle owners on driving safety and reduce environmental pollution but from the initial observations of researchers implementing the KIR e-test, there are still obstacles. In its implementation include:

1. Lack of socialization regarding the KIR e-test in the community by the Department of Transportation, regarding the benefits and implementation procedures, so that there are still people who still use the services of brokers to test it.

2. Human resources in the testing department are still lacking; currently, the number of examiners is nine people even though the average number of motorized vehicles tested per day is 60 general passenger vehicles and goods with a $13 \%$ failure rate, requiring 16 examiners starting from administrative checks, inspections condition of the vehicle until the determination of the feasibility of the vehicle.

3. The competence of examiners still needs to be improved; of the nine examiners who are graduates of the Land Transportation College, only one person has a certificate of competence.

4. If there is damage to the vehicle test equipment due to the dense volume of use, then the testing activity will be slightly hampered; vehicle testing is carried out manually because it does not have backup test equipment.

By looking at the many problems in the implementation of this program, the researchers are interested in conducting further research, which the researchers put in the form of a journal article with the title "Implementation of the KIR E-Test Program in the Technical Implementation Unit of the Motor Vehicle Testing Service of the Garut Regency Transportation Service".

\section{B. METHOD}

In this study, researchers used a qualitative approach with the descriptive analysis method. This method is relevant and following the research, namely to understand the implementation of the KIR e-test program at the Technical Implementation Unit of the Motor Vehicle Testing Service of the Garut Regency Transportation Service in the form of written or spoken words from the informants studied. So the purpose of choosing this qualitative approach is to understand how to process and reveal the meaning of each phenomenon with the theoretical support built 
into the research concept. The data collection techniques used are interviews, observation, and documentation (while the data analysis technique uses the Miles and Huberman model in Sugiyono (2016), which consists of data collection, data reduction, data presentation and conclusion drawing/verification.

\section{RESULT AND DISCUSSION}

Public policy is a process and product produced by the government, which is also known as a series of fundamental decisions because the policy only outlines the basic things as a basis for acting to achieve the goals that have been set (Lascoumes \& Le Gales, 2007). One of its functions is to serve the public interest. According to Friedrich in Wahab (2008), the policy is: "an action that leads to goals proposed by a person, group or government in a certain environment in connection with certain obstacles while looking for opportunities to achieve goals or realize desired goals". Public policy is also stated by Udoji in Wahab (2008) "an active transaction that leads to a problem and a certain group of interrelated problems that affect some members of the community". Dye in Syafiie (2016) said that public policy is whatever the government chooses to do or not do (whatever government chooses to do or not to do), that if the government chooses to do something, then there must be a goal (objective) and public policy. It includes all government actions, so it is not merely a statement of the will of the government or government officials. Alfatih (2010) states that public policy is every decision or action made intentionally and legally by the government to protect the public interest, solve public problems, empower the public, and create public welfare.

According to Agustino (2014), "Implementation is a dynamic process, where policy implementers carry out an activity or activity so that in the end they will get a result that is following the goals or objectives of the policy itself". This understanding means that to implement something, it must be accompanied by supporting facilities that will later impact or affect something (Wahab, 2008). Nugroho in Alfatih, (2010) states "Policy implementation is a way for a policy to achieve its goals". Meanwhile, according to Sunggono (in Wahab, 2008): "Policy implementation is an effort to achieve certain goals with certain means". Thus, what is needed in implementing this policy are legitimate actions or the implementation of a plan according to the objectives. Edward III in Agustino (2014) suggests that policy implementation will be successful if there are 4 (four) critical supporting factors, namely: 1) Communication, 2) Resources, 3) Disposition or attitude of the implementer, 4) Bureaucratic structure According to Edward III states that these four factors can determine the success in implementing a policy because if the implementor ignores these factors, the implementation of the policy will reap failure in its implementation.

To ensure order in society, the government issued a policy of Law No. RI. 22 of 2009 concerning Road Traffic and Transportation, which contains the regulation and guidance of vehicles and drivers that cannot be separated from the traffic and road transport system, which constitutes the national transportation system. To collect data that can be used for orderly administration, control of motorized vehicles operated in 
Indonesia, facilitate the investigation of violations or crimes involving the vehicle in question, as well as in the context of traffic management, technical and roadworthy requirements for motorized vehicles are stipulated and require motorized vehicles to be imported, manufactured and assembled domestically which will be operated on the road to carry out periodic testing of motorized vehicles (KIR). The KIR e-test is an innovation program based on SOPs regarding motorized vehicle inspections to facilitate services to the public and ensure transparency so that in administering the KIR test as regulated in the Minister of Transportation Regulation No. 133 of 2015 concerning Periodic Testing of Motor Vehicles. Periodic Testing of Motorized Vehicles is a series of activities to test and or inspect parts of motorized vehicles, trailers, patch trains and special vehicles in the context of compliance with technical requirements and roadworthiness. Roadworthiness is the minimum condition of a vehicle that must be met to ensure that the vehicle will be safe to operate and not pollute the air and the environment.

To analyze the implementation of the KIR e-test program in the Technical Implementation Unit of the Motor Vehicle Testing Service of the Garut Regency Transportation Service, the researchers analyzed it using Edward III's theory which stated that four critical factors support policy implementation, namely communication, resources, disposition and bureaucratic structure that will be researched. Describe as follows:

\section{Communication}

The innovation of electronic KIR testing needs to be socialized both to policy implementers, namely UPTD PKB Dishub Garut, and the target community of vehicle owners who are required to test. Policy socialization to policy implementers is carried out, so that policy implementers make it a guide in implementing activities. The results of the study that there are still people who have mandatory test vehicles who have not received information about the procedure for testing motorized vehicles electronically can be done quickly and easily, so far the information that has arrived is only in the form of changes in testing from manual to electronic but information on testing procedures has not been informed to the community so that there are still people who think that the testing procedure takes a long time, so that vehicle owners prefer to use the services of brokers in testing because their knowledge of vehicle testing procedures is very minimal.

\section{Resources}

Failures often occur in policy implementation, which is caused by the number of employees who are not sufficient or not competent in their fields. Concerning human resources. So far, officers have experienced difficulties if the volume of vehicles tested reaches 60 vehicles/day. The limited number of testers makes the testing phase a bit hampered. There is still a lack of software and equipment supporting the KIR e-test program where the online registration support software is still inadequate where the software is essential for the continuity of online registration, equipment such as tablets / PCs and online registration support software is relatively expensive, so that the addition takes a long time to complete. Fund budgeting. From 
the observations, it is known that the UPTD PKB Dishub Garut Regency does not yet have a backup of e-KIR infrastructure so that if there is damage to the vehicle test equipment due to the dense volume of usage, then the testing activity becomes slightly hampered, vehicle testing is carried out manually because it does not have a backup test tool.

3. Disposition

Implementing the motor vehicle feasibility test conducted by the UPTD PKB Dishub Garut Regency is still prone to illegal levies (extortion). Several vehicle owners admitted that they were worried about illegal extortion, which usually happens in testing motorized vehicles. From the results of field observations on the KIR e-test program at the UPTD PKB Dishub Garut Regency, all relevant parties gave positive support to the program's implementation. The positive response was also shown by the employees involved in implementing the KIR e-test in the form of a commitment to provide the best service. Meanwhile, the measure of the success of the KIR e-test program is the increase in the number of those who test their vehicles, seen from the number of those who test vehicles, which has consistently increased since the introduction of the KIR e-test and from the enthusiasm of service users who feel that the vehicle testing time is faster and the payment can be made. This is done at Bank Jabar counters anywhere. With this, the public feels that it is easier for people to register, which can be done online, from payments to testing vehicles whose testing system is electronically based with testing equipment using a tablet or personal computer that is connected to the internal application of the UPTD PKB Dishub Garut Regency.

4. Bureaucratic Structure

The stages of testing motor vehicles based on SOPs for motorized vehicle inspections consist of several stages, namely: pre-test, exhaust emission test, underside of vehicle inspection, headlight intensity test, front-wheel knuckle test, scales, brake test, and speedometer test. After motorized vehicles have been tested, people who test their vehicles can immediately take the test results at the available counter, which is no longer printed manually but uses a computer system. Structuring the proper organizational structure by establishing a Regional Technical Implementation Unit (UPTD) for motor vehicle testing with specific duties and responsibilities facilitates coordination, integration and synchronization between work units and existing job descriptions. The placement of reliable workers following their fields maximizes the organization's function following its aims and objectives; the organization/implementing unit can implement policies effectively and efficiently.

Researchers found inhibiting factors in the field, namely:

\section{Socialization}

The communication carried out by the UPTD PKB Dishub Garut Regency to the target group, namely motor vehicle owners is required to have periodic tests based on observations and interviews with researchers. It can be concluded; communication is only carried out regarding the technical implementation of testing, testing costs, and appeals related to testing. Meanwhile, communication efforts to realize the 
importance, benefits, targets of carrying out vehicle testing and the importance of conducting self-tests have not received attention from the UPTD PKB Dishub Garut Regency.

2. There are brokers

There are still brokers in the UPTD PKB Dishub Garut Regency on behalf of the service bureau. On the one hand, the UPTD PKB Dishub Garut Regency always tries to suppress the existence of service bureaus (brokers) who can be troubling to vehicle owners, such as someone who wants to test the vehicle of these illegal service elements bringing along the vehicle documents of someone who will be tested and of course with with different tariffs, these illegal service actors increase the number of tariffs that are not appropriate. The cost of the motor vehicle test carried out when starting the initial test until it ends is Rp. 100,000, but the perpetrators of these illicit services are targeting a tariff of Rp. 250,000 and, of course, in exchange for some convenience if the test participants do not fulfil the requirements for proper testing, with the help of service personnel. In the dark, the vehicle can still carry out periodic testing.

3. Involvement of examiners

The perpetrators of illicit services take advantage of this moment to carry out periodic testing of motorized vehicles by way of the back; of course, in this case, there is involvement between unscrupulous service actors and the UPTD PKB; this is often found at the location of testing motorized vehicles, the perpetrators of illegal services when carrying out their work providing or using a code for testing motorized vehicles with testing officers and only test officers knowing the code even though the general purpose of the KIR e-test is based on interviews with the head of the UPTD PKB testing to reduce illegal fees in motor vehicle testing, speed up vehicle testing time based on IT, make it easier for users in testing the vehicle.

\section{CONCLUSION}

Implementing the KIR e-test program at the UPTD of the Garut Regency Transportation Office has been carried out since October 1, 2019. The KIR e-test program is a service innovation by changing the manual KIR test system using an ITbased system so that the KIR e-test application can simplify and shorten the service time for people who will do the KIR test. In the implementation of the KIR e-test program, there are several obstacles, including 1) Information on changes in testing procedures from manual to electronic has not been informed to the public, so there are still people who think that the testing procedure carried out takes a long time, so that vehicle owners prefer to use service brokers in testing because their knowledge of vehicle testing procedures is minimal. 2) UPTD PKB Dishub Garut still lacks testers, especially certified testers and does not yet have a backup of e-KIR infrastructure so that if there is damage to the vehicle test equipment due to heavy usage volume, then testing activities will be slightly hampered, vehicle testing is carried out manually because don't have a backup test kit yet. 3) Implementation of the KIR e-test is still prone to illegal levies because brokers call themselves service bureaus in collaboration with unscrupulous officers. 


\section{REFERENCES}

1. Agustino, L. (2014). Dasar-Dasar Kebijakan Publik. Bandung: Alfabeta.

2. Al Fatih, A. (2010). Implementasi Kebijakan dan Pemberdayaan Masyarakat. Bandung: UNPAD Press.

3. Chantika, O. D. (2013). Kinerja Organisasi UPTD Pengujian Kendaraan Bermotor Wiyung Kota Surabaya. Jurnal: Kebijakan dan Manajemen Publik, 1, 6-11.

4. Kadarisman, M., Gunawan, A., \& Ismiyati, I. (2016). Kebijakan Manajemen Transportasi darat dan Dampaknya Terhadap Perekonomian Masyarakat di Kota Depok. Jurnal Manajemen Transportasi E Logistik, 3(1), 41-58.

5. Kania, I., Alamanda, D. T., Karmila, M., \& Kurniawan, A. (2020, December). The Resolution of Ojek Online Vs. Traditional Public Transportation Conflict. In Napa Proceedings Conference (pp. 497-511).

6. Kuncoro, S. C., \& Sarbini, D. (2020). Strategi Komunikasi Dinas Perhubungan Surakarta Dalam Mensosialisasikan Program E-Uji Kir (Doctoral Dissertation, IAIN Surakarta).

7. Lascoumes, P., \& Le Galès, P. (2007). Introduction: Understanding Public Policy through Its Instruments-From the Nature of Instruments to the Sociology of Public Policy Instrumentation. Governance, 20(1), 1-21.

8. Law Number 22 of 2009 concerning Road Traffic and Transportation.

9. Minister of Transportation Regulation No. 133 of 2015 concerning Periodic Testing of Motor Vehicles.

10. Minister of Transportation Regulation No. 133 of 2015 concerning Periodic Testing of Motor Vehicles.

11. Moleong, L. J. (2014). Metodologi Penelitian Kualitatif. Bandung: Remaja Rosdakarya.

12. Natika, L., \& Putri, G. N. (2021). Evaluasi Kebijakan Pengujian Kendaraan Umum dan Barang di Dinas Perhubungan Kabupaten Subang. The World of Public Administration Journal, 26-38.

13. Septianti, F. S., \& Prabawati, I. (2019). Implementasi Program E-Uji KIR di Unit Pelaksana Teknis Dinas (UPTD) Pengujian Kendaraan Bermotor (PKB) Tandes Kota Surabaya. Publika, 7(1).

14. Sugiyono. (2016). Metode Penelitian Bisnis (Pendekatan Kuantitatif, Kualitatif, dan $R \mathcal{E} D)$. Bandung: Alfabeta.

15. Syafiie, I. K. (2016). Etika Pemerintahan. Jakarta: Rineka Cipta.

16. Wahab, A. S. 2008. Analisis Kebijaksanaan dari Formulasi ke Implementasi Kebijaksanaan Negara. Jakarta: Bumi Aksara. 